\title{
The Organization Model of Project Activities of Students with Technical Directions Background in Higher Educational Institutions
}

\author{
Dmitry Yu. Voronov ${ }^{1}$, Tatyana N. Popova ${ }^{1}$, Elena M. Voronova ${ }^{1}$, and Olga M. \\ Storozhenko $^{2^{*}}$ \\ ${ }^{1}$ Togliatti State University, Belorusskaya str., 14, 445020, Togliatti, Russia \\ ${ }^{2}$ Bauman Moscow State Technical University, 2nd Baumanskaya str., 5/1, 105005, Moscow, Russia
}

\begin{abstract}
The article analyses the issues of improving the quality of training of technical specialists in higher educational institutions on the basis of project activities. The modern trends of improving project activities are disclosed in the preparation of bachelors in the technical areas of training, also, there are analysed advantages and disadvantages of the approach proposed. The particular attention is paid to issues of intellectual property management in the university circuit. Also, the problems of commercializing the results of intellectual activity created as part of the project activities of students and teachers are noted. It is indicated the necessity for interaction between universities and business representatives to create viable objects of intellectual activity.
\end{abstract}

\section{Introduction}

One of the modern trends of higher education in Russia in the preparation of a highly qualified, sought-after specialist is the expansion of practice-oriented training.

In order to review the actual implementation of the practice-oriented approach in the preparation of students in technical universities, we have proposed an analysis of the work of the Department of Equipment and Technologies of Mechanical Engineering at Togliatti State University. The student design bureau "Machine" was created in the University to teach bachelors the training program "Design and technological support of engineering industries". As part of the project activity, the members of this design bureau were engaged in the development of a three-axis desktop CNC milling machine.

During its creation process, students had to solve a number of organizational and technical issues, which solution allowed us to prepare a methodology for organizing project activities to create a technical object.

The essence of the resolved technical issues is presented in works [1], [2]. At the same time, a significant part of the technical documentation was in a foreign language, which required the development of relevant competencies using the methodology, which is described in the works of Tatarnitseva S. and Mordvinova [3].

\footnotetext{
*Corresponding author: stom@bmstu.ru
} 
At the same time, the development and creation of inventions, utility models and industrial prototypes in the contour of the university is not only one of the areas of practical training of the university, but also it raises the question of the continued viability of the created intellectual property objects. It should be noted that the problem of managing the exclusive rights to innovations created by students and university staff is characteristic not only for Russian, but also for foreign universities as well [4].

\section{Body}

\subsection{The analysis of the results of the inclusion of students' project activities into the educational process}

The necessity for highly qualified specialists will only increase as since the national projects, which are initiated by the President of the Russian Federation are implemented. This is especially true for the technical areas of training, which graduates will have to create and work with real technical objects [5], [6], [7], [8]. The set of competencies here should be wide enough and should consistent with the tasks of modern economic development. One of the ways to achieve this goal - is to include into the educational process project activities, which are aimed at creating a real technical object. This will allow a student to master at a high level the competencies, which are laid down in the Federal State Educational Standard and to be able to apply these skills in real engineering activities.

Indeed, according to the report of the Boston Consulting Group, which was published in 2017 , there is a shortage of qualified personnel, which is necessary for the development of the economy and its transition to a new structure [8]. Following the developed countries of the world - the shortage is up to 10 million people until 2025. The data show the relevance of such training in various industries.

At the Togliatti State University (hereinafter - TSU), at the Department of Equipment and Technologies of Engineering Production, a student design bureau "Machine" was created to teach bachelors of the training program "Design and technological support of engineering industries". In fact, it is a student FabLab, in the work of which students of all courses are involved, and it is a kind of student think tank, which closes all projects in this area of training. The creation of a finished technical object, as a complex engineering task, requires significant time and intellectual costs [8]. Therefore, the "big project" of a technical object creation will be rationally divided into a series of "small projects" that would fit organizationally into the schedule of project activities of the university. Then, the main function of the student design bureau will be the unification of project activity groups within the framework of the "large project", which will allow to obtain a finished technical object.

At the initial stage, the functions of the student design bureau should include the selection of a relevant, sought-after technical object. Currently, the market for the development of 3D devices and similar devices is developing rapidly. Projected growth by 2020 is about of $\$ 20$ billion, i.e. more than 2 times relative to today's indicators. Despite this market is a diverse one, the share of Russia in it is less than $1 \%$. Hence, the relevance of the task - is the development of a three-axis milling machine with numerical control (CNC).

To accomplish this task, it is necessary to draw up a calendar work plan for the design and manufacturing of the machine, under the guidance of a leading teacher on design activities. Here, the teacher acts as a moderator, who formulates tasks for project teams, supervises, gives advices and evaluates student's work. The work of project teams should 
fit into the schedule of project activities of the university. For example, at TSU, project activities are distributed in the class schedule once a week for eight weeks per semester. For convenience, such a schedule could be presented in the form of a Grant diagram, as shown in Figure 1.

\begin{tabular}{|c|c|c|c|c|}
\hline Job List & & & & \\
\hline Job calendar scheduling & & & & \\
\hline State analysis & & & & \\
\hline Patent research & & & & \\
\hline $\begin{array}{l}\text { Calculation of structural } \\
\text { elements of the machine }\end{array}$ & & & & \\
\hline Designing the machine & & & & \\
\hline 1st semester report & & & & \\
\hline $\begin{array}{l}\text { Preparation of design } \\
\text { documentation }\end{array}$ & & & & \\
\hline $\begin{array}{l}\text { Preparation the list of } \\
\text { purchased products }\end{array}$ & & & & \\
\hline 2nd semester report & & & & \\
\hline Machine assembly & & & & \\
\hline 3rd semester report & & & & \\
\hline Machine setup and debugging & & & & \\
\hline 4th semester/ Final report & & & & \\
\hline & 1st semester & 2nd semester & 3rd semester & 4 th semester \\
\hline
\end{tabular}

Fig. 1. An approximate version of the schedule of the list of works.

The teacher-moderator divides students into small groups of 5-7 people. The first group is engaged into the study, analysis and systematization of all scientific and technical information that is available publicly in the Internet in order to find out the best technical solutions, to simplify the design and to reduce the complexity and costs of manufacturing the machine. Moreover, they search of the information should be not only in Russian, but also in foreign languages, for which the group should include at least 1-2 students who are fluent in foreign languages, mainly in English. The second group searches for patent information using the service of the patent office of the Russian Federation - fips.ru. The task of the second group is to check up the technical solutions, which are formed by other groups, for the purposes of violation of someone's intellectual property rights, and to check their own technical solutions for patent purity and patentability. Students of the first and second groups provide online the received data to students of the third and fourth groups. As since the complexity of tasks for students of the first and second groups is less than for the students of the third and fourth groups, from about the fifth week, these groups are disbanded as having completed their task, and students are moved into the third and fourth groups. The third group, using the data of the first and second groups, performs the necessary engineering calculations of various structural elements of the machine. The task of the fourth group, which is based on the data of the three previous groups, using computer technology, is to create the 3D model of a three-axis CNC milling machine. After the seventh week, small design teams are combined into the large one, which is based on the student design bureau, and all together they draw up a semester report on design activities. The purpose of this report is the collection and systematization of information and specific tasks, which are performed by students during the semester, for the purpose of the further work on the design of the machine, according to the schedule of the list of works.

At the next stage, several small design teams of 3-4 people form a set of design documentation for the assembly of the machine. One group is developing a set of drawings for the manufacture and assembly of an X-axis assembly, other groups - develop the same for $\mathrm{Y}$-axes and $\mathrm{Z}$-axes. Also, a group is created to design the general layout. The total 
amount of such groups is 5-6. A separate group is involved in compiling a list of purchased products and in preparation of the documents for their purchase. At the eighth week, small groups are combined into one large group to compile a semester report. The group that was preparing the documentation for their procurement of products is not finally disbanded until about the second week of the next semester, in order to control the procurement process, which continues during the inter-semester period. As since any additional purchases could be necessary.

The stage of the third semester is characterized by high complexity and intensity of work. In addition, this stage requires from the students to have certain qualifications in assembling machine tools. The role of the teacher-moderator is very high. He needs to identify and appoint as the head of small project groups of 3-4 people, students who have mastered professional competencies. These design teams are engaged in the manufacture of machine parts and its assembly. The leading teacher of project activities distributes the work in such a way as to align the load of students in different groups. This will ensure synchronization in the assembly process of the machine. If necessary, students could be transferred by the teacher from one small project group into another. In the eighth week, similar to the previous stages, small groups of project activities are combined into one large group for the preparation of the semester report. As a part of a report on project activities, there is also a material object - a machine tool, which is ready for approximately $70 \%$.

At the last stage in the development and assembly of a three-axis CNC milling machine, it is set up and debugged, the necessary set of devices is installed, in accordance with safety requirements, the machine is checked and sample parts are produced on it. The difference in project activities in the third semester is that six weeks are allocated to the practical part. The last two weeks are devoted to compiling a semester and to the final presentation report on the project activities results. Figure 2 shows a finished three-axis CNC milling machine, performed by students of the training program "Design and technological support of engineering industries".

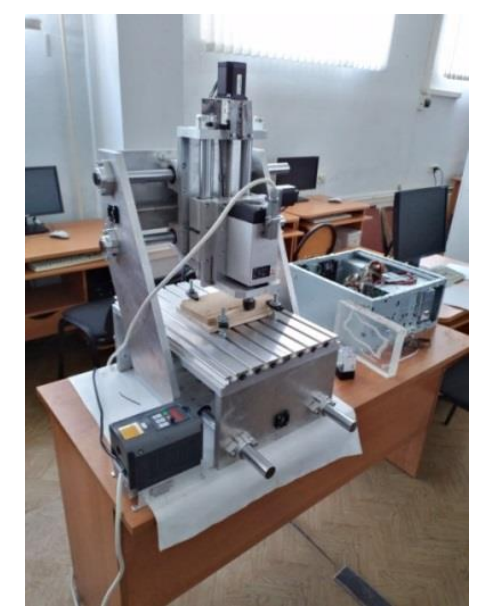

Fig. 2. Three-axis CNC milling machine, the result of design activities.

Based on the above information, this approach to the organization of project activities of students in technical areas of universities has several significant advantages and it is implemented successfully in practice. The main advantage of this approach is the mastery of students in practice of making a real technical facility. At the same time, students from the training program 15.03.05 "Design and technological support of engineering industries" applied all general cultural, general professional and professional competencies presented in the Federal State Educational Standard, which, in combination with the usual disciplines, 
gives a synergistic effect during the process of a specialist's training. Therefore, we can say that this approach to the organization of project activities contributes to the goal of obtaining a highly qualified technical specialist at the university.

The next aspect that deserves attention is the opportunity for students to participate in various exhibitions, conferences, forums, with a real technical object. This approach helps students to receive grants, helps in obtaining funding for the START UP programs, or, for example, «UMNIK». Students have real material for preparing publications [10].

Thus, participation with real projects in these activities by students contributes to their mastery of professional competence.

Achievements of students improve the performance of the department in general. The rational use of the potential of active students involves unification within the framework of the student bureau, which allows us to solve problems of a higher level, by systematizing and rationalizing work on all projects of project activities. Using the student bureau as such an association, we have the opportunity to participate in programs and grants, which are aimed at the development of student's associations.

Another aspect of applying the results of students' project activities is the possibility of organizing the educational process on a manufactured machine. For example, for the discipline "Metal-cutting machines" of bachelors in the training program "Design and technological support of engineering industries", one could create a series of laboratory works performed on this equipment. In addition, on the basis of laboratory work data, one could create a program of continuing education courses for subject matter specialists or a program for the young people teaching of the basics of programming for CNC machines. We can state the fact that the result of students' project activities has applied value in the field of advanced training and youth leisure organization. Another example of the application of these results of project activities is the possibility of using this machine in the processing of real parts of the corresponding overall dimensions, for example, as part of contractual work.

Consequently, the methodology of students' project activities aimed at creating a real technical object contributes to the formation of a synergistic effect to improve the quality of mastering the general and professional competencies of the educational program, it creates conditions for increasing the publication and grant activity of students, and it has applied value in the field of advanced training and organization of youth leisure, and it could be used also in real manufacturing of products.

\subsection{The effectiveness of the educational process for the creation of sustainable project results}

A logical continuation of the project activity is the creation of potentially viable results of intellectual activity, ensuring their legal protection and accounting in the university circuit, as well as ensuring the life cycle of the created result of intellectual activity by determining its future fate [11]. The above determines the tasks that are set for the students' project activities: the results of such work should be protectable and commercially attractive. For this, students should be able, even at the stage of creation, to choose the appropriate form of legal protection for the future result of project activities and to model possible directions for the commercialization of such results of intellectual activity [12], [13], [14], [15]. The training of modern engineers should include the development of this competence so that the process of creating the result of intellectual activity is not "divorced" from the further process of its implementation in civilian circulation.

However, in modern educational organizations, the creation of the results of intellectual activity and means of individualization is not oriented to the intellectual property market and often does not have prospects for commercialization; for faculty members, the creation 
of such facilities takes place within the framework of official duties; for students, the creation of the results of intellectual activity is an element of training and solving research problems in the process of performing research work and final qualification work; often the creation of intellectual property is the fulfilment of key indicators of the university, faculty.

The abovementioned problems of modern universities should be taken into account during developing the educational organization management policy. Today we can confidently assert that an effective educational process in a modern university is connected, inter alia, with a policy of managing intellectual property rights. So, at the state level, the Model Provision of the World Intellectual Property Organization was adapted for the Russian Federation and the "Policy in the field of intellectual property for universities and research organizations" was approved. Particular attention in the study of the development and implementation of the Intellectual Property Rights Management Policy at the university was given in the works of A. Karpov [16], B.N. Korobets E.A. [17], E.A. Salitskaya [18] and others.

As it is noted above, students' project activities include the creation of intellectual property objects that should be potentially attractive to the market. In this sense, it is of particular importance to take into account the concept of the "triple helix" in the implementation of the strategy of universities' innovative development. Its essence lies in the direct interaction of government, business and universities, which are the key elements of the system. In this model, the state should play a facilitating role; business - should ensure the order and financing of R\&D and to inform about their needs; universities, in cooperation with research institutes should carry out R\&D and develop innovative infrastructure; research institutes - should provide general guidance on the implementation of research and development by universities, should intensify the process of transferring intellectual property to business.

In world's practice, the model "University - Industry - Government" is one of the most notable. In Russia, "double spirals" are currently being developed, representing the following pairs: the state - fundamental science; science - business; the state - resourcebased industries; the state - the rest of the business.

Universities should be participants in sectoral and regional economic development processes. The purpose of the development of this concept is the influence of universities on the regional labour market and job creation in priority sectors of economic development. This could be achieved through the interaction of science education and innovation. The concept of open innovation involves the creation of "innovative regional clusters" and "technology platforms" with the participation of universities [19].

\section{Conclusion}

The use of innovative technologies affects all spheres of human activity, and education should always be at the forefront of innovative development, and its methodology should meet the requirements of such development. Accordingly, this imposes requirements on graduates to an independent, creative approach to their work, in the conditions of constantly changing conditions and requirements of modern production. For the formation of highly qualified specialists, in addition to studying the disciplines of the general professional and general cultural cycle, a constant implementation of the knowledge and competencies in practice is necessary.

Such an approach to the educational activity could be organized within the framework of the proposed in the article project methodology with the obligatory development and manufacturing of a real technical object. As shown above, such a methodology makes it possible to improve the quality of specialist training due to the emergence of a synergistic 
effect when combining theoretical training with the practice of implementing theoretical knowledge during the design and manufacturing of a real technical object.

Based on the described methodology of project activities, students, who have produced a real technical object, receive both advantages in obtaining various grants and funding for various STARTUP programs for the implementation of their further research, as well as good material for publications, which stimulates publication activity and contributes to further training [20].

The usage of this approach to project activities has also a significant applied effect in the form of creating a laboratory environment on the basis of the manufactured technical object for student training, advanced training and organizing youth leisure activities in the field of working with 3D- and similar devices.

In conclusion, it would be noted that the technical object, which was developed and manufactured by students in the process of project activity is a full-fledged machine unit, and it could be used in real production.

\section{References}

1. N.Yu. Loginov, D.G. Levashkin, A.A. Kozlov, V.A. Gulyaev, The educational model of project-oriented training of young professionals technical and engineering directions, the concept Industry 4.0. Engineering education, vol. 23, pp. 77-82 (2018).

2. N. Loginov, D. Levashkin, A. Kozlov, M. Borovitskaya, V. Gulyaev, The ProjectOriented Educational Model for Training of Young Engineering Professionals on the Example of the Project "CNC-Team", Proceedings of the 2019 International Conference on Pedagogy, Communication and Sociology, ICPCS, pp. 78-81 (2019). DOI: https://doi.org/10.2991/icpcs-19.2019.18.

3. S.N. Tatarinsteva, O. Mordvinova, Formation of the methodological competence of a linguist-teacher in the process of reading scientific and methodological literature. Actual problems of theoretical and applied linguistics and optimization of teaching foreign languages (In Russian), Togliatti State University, pp. 253-260 (2012).

4. V. Sterzi, M. Pezzoni, F. Lissoni, Patent management by universities: evidence from Italian academic inventions, Industrial and Corporate Change, vol.28 (2), pp.309-330 (2019). DOI: 10.1093/icc/dty070.

5. P.P. Baranov, A.Yu. Mamychev, A.A. Plotnikov, D.Yu. Voronov, E.M. Voronova, Problems of legal regulation of Robotics and Artificial Intelligence in Russia: Some approaches to the solution, Dilemas Contemporaneos-Educacion Politica Y Valores, vol. 6, № SI, Article number 34 (2019).

6. A. Chehri, G. Jeon, The Industrial Internet of Things: Examining How the IIoT Will Improve the Predictive Maintenance. Innovation in Medicine and Healthcare Systems, and Multimedia, pp. 517-527 (2019).

7. A. Chehri, Y.N. Mouftah, Autonomous vehicles in the sustainable cities, the beginning of a green adventure, Sustainable Cities and Society, vol.51, Article number 101751 (2019). DOI: 10.1016/j.scs.2019.101751.

8. About project boards on GitHub // https://help.github.com/en/github/managing-yourwork-on-github/about-project-boards

9. M.G. Sergeeva, O.M. Storozhenko, and more, Organization of career support and development by means of building and individual educational trajectory, Revista San Gregorio, vol.30, pp.43-49 (2019). 
10. N.V. Vinogradova, G.M. Zemlyakova, Pedagogical engineering as a means of forming the scientific and methodological thinking of students in the field of training (In Russian), 44.04.01 Pedagogical Education, Journal ASR: Pedagogy and Psychology, vol.7, \#1 (22) (2018).

11. A. Kashyap, R. Agrawal, Scale development and modeling of intellectual property creation capability in higher education, Journal of Intellectual Capital, vol.21, pp.115138 (2019). DOI: 10.1108/JIC-09-2018-0168.

12. O.M. Shcherbakova, O.Yu. Otrokova, V.I. Burenina, (ICCESSH 2019) Russian method of training engineering personnel: historical experience and modernity, Advances in Social Science, Education and Humanities Research Proceedings of the 4th International Conference on Contemporary Education, Social Sciences and Humanities, pp. 645-650 (2019).

13. V. Volochienko, S. Falko, E. Postnikova, Recognition of the problematic situations in industrial systems with intellectual support, International Journal of Mathematical, Engineering and Management Sciences, 4(6), pp. 1434-1447 (2019). DOI:10.33889/IJMEMS.2019.4.6-113.

14. O.V. Vidyakina, Development of Patent policy at the University (In Russian), Monograph, Moscow, p. 125 (2012).

15. A.V. Kolesnikov, T.M. Stepanyan, O.M. Storozhenko, and more, Complications of Russian innovative development financing, International Transaction Journal of Engineering, Management, \& Applied Sciences \& Technologies (2019). DOI: 10.14456/ITJEMAST.2019.109.

16. A. Karpov, Modern university as an economic growth driver: Models \& missions, Voprosy Ekonomiki, (3), pp. 58-76 (2017). DOI:10.32609/0042-8736-2017-3-58-76.

17. B.N. Korobets, Models for technology programmes within an intellectual property management system, Herald of the Bauman Moscow State Technical University, Series Natural Sciences, (6), pp. 135-142 (2016). DOI:10.18698/1812-3368-2016-6-135-142.

18. E.A. Salitskaya, The Problem of Unprotected Content of Scientific Work, Do We Need a "Copyright” on Ideas?, Herald of the Russian Academy of Sciences, № 5 (Vol. 89), pp. 460-467 (2019). DOI:10.1134/S1019331619050095.

19. U. Kaiser, H.C. Kongsted, K. Laursen, A.K. Ejsing, Experience matter: The role of academic scientist mobility for industrial innovation, Strategic Management Journal, vol. 39 (7), pp.1935-1958 (2018). DOI: 10.1002/smj.2907.

20. M.G. Sergeeva, N.N. Bedenko, T.Y. Tsibizova, M.S. Mohammad Anwar, T.G. Stanchuliak, Organisational economic mechanism of managing the growth of higher education services quality, Espacios, 39(21) (2018). Retrieved from www.scopus.com. 